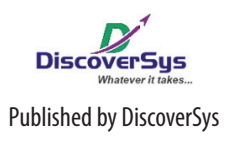

Published by DiscoverSys

\section{Perception of nursing staff towards the application of Professional Nursing Care Model and job satisfaction at Sanjiwani Hospital, Gianyar}

\author{
Gusti Ayu Krisma Yuntari, ${ }^{1}$ Pande Putu Januraga, ${ }^{2}$ I Ketut Suarjana ${ }^{2}$
}

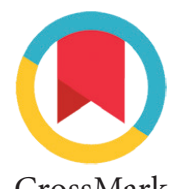

CrossMark

\title{
ABSTRACT
}

Background and purpose: Several hospitals in Indonesia have developed a model of nursing care known as MAKP (Professional Nursing (are Model) to improve the quality of nursing services. Sanjiwani Hospital, Gianyar has applied this model. The aim of this study is to explore the perception of nurses towards this approach and assess its association with job satisfaction.

Methods: A cross-sectional survey was conducted with 92 nurses working at the inpatient ward at Sanjiwani Hospital, Gianyar. Data were collected from July-August 2017 by interview using questionnaires. Data collected included the characteristics of respondents (age, gender, education, and employment status), nurses' perception towards the application of MAKP, and nurses' job satisfaction.

Results: Nursing staff demonstrated perception score of $\geq 15$ on leadership elements (68.5\%), communication (72.2\%), coordination (84.8\%), delegation (80.4\%), and supervision (66, $3 \%)$. Nursing staff with a score of $\geq 15$ in coordination perception $(A O R=4.48 ; 95 \% C l: 1.14-17.54)$, delegation $(A O R=4.00 ; 95 \% \mathrm{Cl}$ : 1.21-13.23) and supervision ( $A O R=3.35 ; 95 \% \mathrm{Cl}$ : 1.25-8.88) expressed higher job satisfaction. While aspects of leadership $(A O R=0.98 ; 95 \% C l: 0.29-3.79)$ and communication $(A O R=0.76$; $95 \% \mathrm{Cl}: 0.19-3.05)$ were not significantly associated with job satisfaction.

Conclusions: The majority of nurses have a positive perception towards the MAKP approach. The better perception on coordination, supervision and delegation are found to increase job satisfaction. The results imply that coordination, supervision and delegation should be considered in order to increase job satisfaction in other hospitals.

Keywords: Professional Nursing Care Model, job satisfaction, Gianyar, Bali

Cite This Article: Yuntari, G.A.K., Januraga, P.P., Suarjana, I.K. 2018. Perception of nursing staff towards the application of Professional Nursing Care Model and job satisfaction at Sanjiwani Hospital, Gianyar. Public Health and Preventive Medicine Archive 6(1):68-72. D01:10.15562/phpma.v6i1.12

${ }^{1}$ Sanjiwani General Hospital, ${ }^{2}$ Department of Public Health and Preventive Medicine, Faculty of Medicine, Udayana University
*Correspondence to: Gusti Ayu Krisma Yuntari, Sanjiwani General Hospital, tareeeajah@yahoo.com

\section{INTRODUCTION}

Nursing service provision is a reflection of the quality of services at a hospital because the nursing service lasts 24 hours and the nurse is one of the most dominant health personnels in the hospital. ${ }^{1}$ One strategy to ensure the quality of nursing services provided is to establish guidelines for service provision.

The choice of nursing care approach is dependent on the situation and condition of the hospital. The selected nursing care model should be able to improve the nurses' performance, not to increase the workload, and to work towards facilitating service provision. ${ }^{2}$ Based on previous systematic reviews, it is evident that applying primary nursing care guidelines can improve nursing service and nurse autonomy, but not have an impact on job satisfaction. ${ }^{3}$ One of the frameworks for professional nursing care that is being developed in Indonesia is Professional Nursing Care Model or in Bahasa Indonesia abbrevation is MAKP. This nursing care framework is a modification or combination between the team model and the primary nurse model. The application of MAKP modification of the primary team is dependent on the situation and condition of the hospital, wherein an eligible hospital only has the graduate nursing staff or nurses with the equivalent education levels. On the other hand, some hospitals are unable to adopt the MAKP team approach because of the fragmentation of duties among nursing staff. A combination and modification of the two models, is an alternative to professional nursing care, as currently, many nurses in hospitals in Indonesia have only achieved a nursing diploma, not a degree. ${ }^{4}$ There are five elements in the implementation of MAKP namely leadership, communication, coordination, delegation and supervision. ${ }^{5}$ These aspects act as indicators for the effective implementation of nursing care.

MAKP has been rolled out in several hospitals in Indonesia, including in Dr. Saiful Anwar Hospital, Malang. In a review of the implementation of MAKP at the hospital above, it was evident that aspects of promotion, supervision, teamwork and working conditions impacted upon nurse job satisfaction. ${ }^{6}$ A study at Wangaya Hospital, Denpasar showed that there was a relationship between the implementation of MAKP with the level of patient satisfaction. ${ }^{7}$ 
Sanjiwani Hospital in Gianyar, is one of the public hospitals in Bali that has adopted the MAKP modification approach as of July 2015. Until now there has been no evaluation of nurse work satisfaction towards the application of MAKP. The results of preliminary observations and interviews with nurses by researchers (January 2017) indicated that there are some problems with MAKP implementation which lead to increased workload and dissatisfaction among community nurses. Interview by researchers with the chief of nurse showed the slow handling of patients was associated with situational factors and that ward management has been less than optimal. In addition, personal communications with ten nursing staff indicated that there had never been any training on the application of MAKP.

The aim of this study is to explore the perception of nurses about MAKP and assess its association with job satisfaction in the inpatient ward at Sanjiwani Hospital, Gianyar.

\section{METHODS}

A cross-sectional survey was conducted at Sanjiwani Public Hospital, which is one of the referral hospitals in East Bali. The implementation of MAKP has been initiated at the inpatient ward at Sanjiwani Hospital since 2005. A total of 92 nurses who were given the authority and assigned to provide nursing services directly to the patients were included in the study.

Data were collected in June-July 2017 through interviews conducted by the researcher using

Table 1 Characteristics of respondents

\begin{tabular}{lll}
\hline Characteristics & $\mathbf{f}$ & $\%$ \\
\hline Age & 25 & 27.2 \\
$\quad 20-29$ years & 44 & 47.8 \\
$30-39$ years & 23 & 25.0 \\
$\quad>40$ years & & \\
Gender & 18 & 19.6 \\
$\quad$ Male & 74 & 80.4 \\
$\quad$ Female & & \\
Education & 63 & 68.5 \\
$\quad$ Nursing diploma & 29 & 31.5 \\
$\quad$ Nursing degree & & \\
Duration of working & 43 & 46.7 \\
$\quad \leq 12$ years & 49 & 53.3 \\
$\quad>12$ years & & 79.3 \\
Status & 73 & 20.7 \\
$\quad$ Civil servant & 19 & 100.0 \\
$\quad$ Contract (temporary) worker & 92 & \\
Total & &
\end{tabular}

standardised questionnaires. Data collected included nurse characteristics (age, gender, education, duration of working and employment status), nurses' perceptions of the application of MAKP and job satisfaction. The nurses' perceptions are measured in 5 aspects of each element of leadership, communication, coordination, delegation and supervision. ${ }^{5}$ Likert scale was used with the score of 1 for 'disagree, 2 for 'less agree', 3 for 'agree' and 4 for 'strongly agree, and the total score for each element is 20 . The leadership element was measured from the aspects of role, role models, leadership styles and rewards. The communication element was measured in the aspects of type, process, strategy and communication barriers. The coordination element was measured in the aspects of coordination within the team, with related units and other health teams. The delegation element was measured in the aspects of ability and authority, fairness, and timeliness of the assignment. Lastly, the element of supervision was measured in the aspects of the role of supervisor, schedule and type of supervision. The nurses perception was categorized into two for each element using the median value as the cut off point. In this study the same median of 15 was found for each element, so the score $\geq 15$ was categorized as satisfactory and the score $<15$ was categorized as less satisfactory. In this study, job satisfaction was measured using the Index of Work Satisfaction Questionnaire Scale, which measures aspects of salary, autonomy, policy, organization, interaction, and professional status through 30 questions. ${ }^{8}$ However, the questionnaire was modified into 25 questions without measuring aspects of salary. This questionnaire also used the Likert scale with the categories as above, so the total score is 100 . Respondents were categorized as 'satisfied' if the score was $\geq 75$ and 'not satisfied' if the score was $<75$, where the value 75 is the median value. The written informed consent was obtained from the respondents prior to the data collection.

Data were analysed using STATA SE 12.1. Bivariate analysis with chi-square test was used to determine job satisfaction based on nurses' perception towards the application of MAKP, and multivariate analysis using logistic regression. This study has obtained ethical clearance from the Human Research Ethics Committee Faculty of Medicine Udayana University/Sanglah General Hospital, Denpasar, Bali on June 2, 2017.

\section{RESULTS}

Table 1 shows that the majority of nursing staff aged $30-39$ years $(47.8 \%)$ and were female $(80.4 \%)$. Most of the respondents had diplomas (68.5\%), with duration of working $>12$ years $(53.3 \%)$ and were civil servants. 
Table 2 Perception of respondents on the implementation of MAKP

\begin{tabular}{|c|c|c|c|c|c|}
\hline Elements & $\mathrm{D}(\%)$ & LA (\%) & $A(\%)$ & SA (\%) & Total (\%) \\
\hline Perception of leadership (positive) & & & & & 68.5 \\
\hline The chief nurse is a good leader & 7.6 & 16.3 & 48.9 & 27.2 & \\
\hline The primary nurse is a good role model & 3.3 & 4.3 & 72.8 & 19.6 & \\
\hline Primary nurses are democratic in their work & 3.3 & 8.7 & 66.3 & 21.7 & \\
\hline The primary nurse makes the right decisions & 4.3 & 6.5 & 76.1 & 13.0 & \\
\hline Nursing staff perform the job in accordance with the assignment. & 3.3 & 4.3 & 68.5 & 23.9 & \\
\hline Perception of communication (positive) & & & & & 72.2 \\
\hline The chief nurse always delivers the information clearly to each team & 5.4 & 8.7 & 65.2 & 20.7 & \\
\hline The primary nurse always discusses the problem & 2.2 & 9.8 & 72.8 & 15.2 & \\
\hline Nursing staff attends the meeting of each shift change in the team & 0 & 9.8 & 69.6 & 65.2 & \\
\hline Nursing staff communicates well with the primary nurse & 3.3 & 5.4 & 65.2 & 26.1 & \\
\hline Nursing staff administers the nursing notes to the other nurses on the next shift & 2.2 & 1.1 & 68.5 & 28.3 & \\
\hline Perception of coordination (positive) & & & & & 84.8 \\
\hline The chief nurse works well with other units & 2.2 & 5.4 & 69.6 & 22.8 & \\
\hline The primary nurse works well with team members & 1.1 & 1.1 & 71.7 & 26.1 & \\
\hline The primary nurse helps other teams & 0 & 6.5 & 69.6 & 23.9 & \\
\hline The primary nurse coordinates well with other teams & 0 & 7.6 & 70.7 & 21.7 & \\
\hline The primary nurse problem solves with other team members. & 0 & 4.3 & 76.1 & 19.6 & \\
\hline Perception of delegation (positive) & & & & & 80.4 \\
\hline The primary nurse delegates to nursing staff & 4.3 & 8.7 & 72.8 & 14.1 & \\
\hline The primary nurse clearly gives direction to the nursing staff & 0 & 7.6 & 79.3 & 13.0 & \\
\hline The primary nurse allocates work fairly & 2.2 & 7.6 & 77.2 & 13 & \\
\hline Work is allocated in accordance with nursing staff capabilities & 0 & 5.4 & 80.4 & 14.1 & \\
\hline $\begin{array}{l}\text { Nursing staff within designated timeframe completes duties assigned by the } \\
\text { primary nurse. }\end{array}$ & 1.1 & 3.3 & 81.5 & 14.1 & \\
\hline Perception of supervision (positive) & & & & & 66.3 \\
\hline The chief nurse provides appropriate supervision & 2.2 & 6.5 & 78.3 & 13.0 & \\
\hline The primary nurse assists the nursing staff in problem-solving & 1.1 & 8.7 & 77.2 & 13 & \\
\hline The primary nurse is a good leader & 2.2 & 5.4 & 80.4 & 12 & \\
\hline The primary nurse provides proper direction & 1.1 & 12 & 76.1 & 10.9 & \\
\hline The primary nurse treats nursing staff with equity & 1.1 & 10.9 & 73.9 & 14.1 & \\
\hline
\end{tabular}

Notes: $\mathrm{D}=$ disagree, $\mathrm{LA}=$ less agree, $\mathrm{A}=$ Agree, $\mathrm{SA}=$ strongly agree

Table 2 presents data on the perception of nursing staff towards MAKP application. The majority of nurses expressed a positive perception on leadership (68.5\%), communication (72.2\%), coordination $(84.8 \%)$, delegation (80.4\%), and supervision (66.3\%).

Bivariate analysis shows that there is no significant association between demographic characteristic variables with job satisfaction.

Table 3 indicates that there is a significant relationship between the perception of nurses regarding the element of coordination with job satisfaction $\quad(\mathrm{AOR}=4.48 ; \quad 95 \% \mathrm{CI}: \quad 1.14-17.54)$, delegation ( $\mathrm{AOR}=4.00 ; 95 \% \mathrm{CI}: 1.21-13.23)$ and supervision (AOR=3.35; 95\%CI: 1.25-8.88). These findings show that better coordination, satisfactory delegation and satisfactory supervision tended to increase job satisfaction. It was shown that the proportion of respondents who perceived communication as satisfactory has higher proportion of job satisfaction, however it is not statistically significant (AOR=0.76; 95\%CI: 0.19-3.05). A similar figure was also found in the nurses' perception towards leadership element ( $\mathrm{AOR}=0.98$; 95\%CI: 0.29-3.79).

\section{DISCUSSION}

This study explores the perception of nurses on the application of MAKP. It was found that some elements of MAKP framework have an association 
Table 3 The relationship between nurses' perception of MAKP with job satisfaction

\begin{tabular}{|c|c|c|c|c|c|c|c|c|}
\hline \multirow[b]{3}{*}{ MAKP } & \multicolumn{4}{|c|}{ Job satisfaction } & \multirow[b]{3}{*}{ p-value } & \multirow[b]{3}{*}{ Adjusted OR } & \multicolumn{2}{|c|}{$95 \% \mathrm{Cl}$} \\
\hline & \multicolumn{2}{|c|}{ Not satisfied } & \multicolumn{2}{|c|}{ Satisfied } & & & \multirow[t]{2}{*}{ Low } & \multirow[t]{2}{*}{ High } \\
\hline & $\mathbf{n}$ & $\%$ & $\mathbf{n}$ & $\%$ & & & & \\
\hline \multicolumn{9}{|l|}{ Leadership } \\
\hline Less satisfactory & 14 & 48.3 & 15 & 51.7 & 0.17 & 0.98 & 0.29 & 3.79 \\
\hline Satisfactory & 21 & 33.3 & 42 & 66.7 & & & & \\
\hline \multicolumn{9}{|l|}{ Communication } \\
\hline Less satisfactory & 12 & 57.1 & 9 & 42.1 & 0.04 & 0.76 & 0.19 & 3.05 \\
\hline Satisfactory & 23 & 32.4 & 48 & 67.6 & & & & \\
\hline \multicolumn{9}{|l|}{ Coordination } \\
\hline Less satisfactory & 10 & 71.4 & 4 & 28.6 & 0.005 & 4.48 & 1.14 & 17.54 \\
\hline Satisfactory & 25 & 32.1 & 53 & 67.9 & & & & \\
\hline \multicolumn{9}{|l|}{ Delegation } \\
\hline Less satisfactory & 12 & 66.7 & 6 & 33.3 & 0.005 & 4.00 & 1.21 & 13.23 \\
\hline Satisfactory & 23 & 31.1 & 51 & 67.9 & & & & \\
\hline \multicolumn{9}{|l|}{ Supervision } \\
\hline Less satisfactory & 18 & 58.1 & 13 & 41.9 & 0.005 & 3.35 & 1.25 & 8.88 \\
\hline Satisfactory & 17 & 27.9 & 44 & 72.1 & & & & \\
\hline Total & 35 & 38.0 & 57 & 62.0 & & & & \\
\hline
\end{tabular}

on job satisfaction, which are, perception regarding coordination, supervision and delegation. On the other hand, leadership and communication were not significantly associated with job satisfaction.

The application of MAKP is relatively new to hospitals in Indonesia, so this study is the first in Bali and first to be published in Indonesia. As a consequence, there is a paucity of published research related to the application of MAKP. Therefore, researchers tried to compare the results of our study with some other studies that have similarities and similar scope of the study.

The finding of this study revealed that better coordination tend to increase job satisfaction. Coordination variables in our study were measured in the aspects of teamwork, either between teams, with other units or other health workers. A study conducted at the inpatient ward at BRSUD Waled Hospital, Cirebon District, West Java was limited to measuring teamwork and proving that this had an association upon job satisfaction and productivity. ${ }^{9}$ In the study using the MAKP team approach at the inpatient ward of the Tangerang District Public Hospital, the measurement of coordination elements used an instrument similar to that within our study, and indicated similar results. ${ }^{10}$ This present study shows that although team coordination was perceived as satisfactory, there were remaining poor nurse perceptions of primary nurse coordination with other teams (7.6\%) and cooperation of the chief nurse with other units (7.6\%).
This study also shows that better supervision tended to increase job satisfaction. This finding is similar with a study conducted at Dr. Saiful Anwar Hospital, Malang. ${ }^{6}$ Our study, however, is not consistent with previous study conducted at the Indonesian Air Force (TNI Angkatan Udara) Yogyakarta General Hospital, ${ }^{11}$ which showed no relationship between supervision and job satisfaction.

Satisfactory delegation was also shown to increase job satisfaction among nursing staff in this study. A similar study conducted in Tangerang District Hospital in the application of team method indicated that positive perception about delegation can help to ensure job satisfaction. The study found that delegation between the chief nurse and the team leader can provide clear directions and steps for the nurse in service provision for patients..$^{10} \mathrm{Our}$ results, however, show that primary nurses had not been able to delegate tasks well to nurses.

In this present study, nurses' perception towards leadership was not significantly associated with job satisfaction. This result was consistent with a study conducted at Dr. M. Djamil Padang Hospita ${ }^{12}$ and in Undata Palu Hospital. ${ }^{13}$ Furthermore, the proportion of nursing staff with positive perceptions of leadership in our study tended to be low. This figure may be related to the fact that the chief nurse has only achieved a diploma level of education. A study at a hospital in Jakarta found that a highly educated person would be more rational, 
creative and adaptable to changes, therefore associated with productivity in carrying out duties. ${ }^{14}$

In our study, the association between the perception of nurses towards communication and job satisfaction was not significant. This finding is consistent with a study conducted at the inpatient ward at Tanggerang District General Hospital and Nganjuk District Hospital, East Java. ${ }^{15}$

This study indicates that the application of MAKP at the inpatient ward at Sanjiwani Hospital has had a positive association with job satisfaction. The finding of this study can be considered by the Management of Sanjiwani Hospital, Gianyar to optimize the implementation of MAKP in order to achieve optimal nurse performance. This study was only conducted in one hospital, therefore the implementation of the findings into other hospitals should be taken in caution.

\section{CONCLUSION}

The majority of nurses have a positive perception towards the MAKP approach. The better perception on coordination, supervision and delegation are found to increase job satisfaction. The results imply that coordination, supervision and delegation should be considered in order to increase job satisfaction in other hospitals.

\section{ACKNOWLEDGEMENT}

We would like to thank the staff of Sanjiwani Hospital, Gianyar for their support and to all respondents for their participation in this study.

\section{REFERENCES}

1. Gillies D. Nursing management: a system approach. 4th edition. Philadelphia: WB. Saunders Company. 1999.

2. Nursalam. Manajemen keperawatan (Nursing management). Jakarta: Salemba Medika. 2011.

3. Mattila E, Pitkänen A, Alanen S, et al. Nursing and care, the effects of the primary nursing care model: A systematic review. Journal of Nursing \& Care. 2014; 3: 3-12.

4. Sitorus. Model Praktik Keperawatan Profesional di rumah sakit (Professional Nursing Care Model in hospital). Jakarta: EGC, 2006.

5. Marquis BL, Huston CJ. Leadership roles and management function in nursing: therory and application. 5th edition. Philadelphia: Lippincott Williams \& Wilkins., 2012.

6. Andriani L. Kepuasan kerja perawat pada aplikasi metode tim primer dalam pelaksanaan tindakan asuhan keperawatan (Studi kuantitatif di Rumah Sakit Dr. Saiful Anwar Malang) (The satisfaction of nurses in the aplication of primary team in the implementation of nursing care (A quantitative study at Dr. Saiful Anwar Hospital, Malang)). Jurnal Aplikasi Manajemen. 2012; 10(2): 419-424.
7. Wulandari, S., Suardana, K., Triyani P. Hubungan pelaksanaaan MAKP metode penugasan perawat primer modifikasi dengan tingkat kepuasaan pasien di Ruang Cendrawasih RSUD Wangaya Denpasar tahun 2012 (Relationships of Professional Nursing Practice Model, modified primary nursing method implementation with patientâs satisfaction level in Cendrawasih Ward at Wangaya Hospital Denpasar, 2012). Available at: http://download.portalgaruda. org/article.php?article $=195800 \& v a l=956 \&$ title $=$ Relationships of Professional Nursing Practice Model-Modified Primary Nursing Method Implementation With Patientâs Satisfaction Level In Cendrawasih Ward at Wangaya Hospital Denpa (2012).

8. Stamps. Nurses and work satisfaction: An index for measurement. 2nd edition. Chicago: Health Administration Press. 1997.

9. Muadi. Hubungan iklim dan kepuasan kerja dengan produktivitas kerja perawat pelaksana di instalasi rawat inap BRSUD Waled Kabupaten Cirebon (tesis) (The association of working atmosphere and job satisfaction with the productivity of nurses in inpatient ward Waled Hospital, Cirebon (thesis)). Universitas Indonesia, 2009.

10. Rusmianingsih N. Hubungan penerapan metoda pemberian asuhan keperawatan tim dengan kepuasan kerja perawat di instalasi rawat inap Rumah Sakit Umum Kabupaten Tangerang (tesis) (The association between the implementation of team nursing care and nurses' work satisfaction in inpatient ward Tangerang District Hospital). Universitas Indonesia, 2012.

11. Wolo PD, Trisnawati R, Wiyadi. Faktor-faktor yang mempengaruhi kepuasan kerja perawat pada RSUD TNI AU Yogyakarta (Factors associated with the nurses' job satisfaction at TNI AU (Indonesian Air Force) Hospital Yogyakarta). Jurnal Ekonomi Manajemen Sumber Day. 2015; 17: 25-34.

12. Transyah $\mathrm{CH}$. Faktor-faktor yang berhubungan dengan kepuasan kerja perawat pelaksana di ruang rawat inap RSUP Dr. M. Djamil Padang tahun 2012 (tesis) (Factors associated with the nurses' job satisfaction in inpatient ward, Dr. M. Jamil General Hospital Padang, 2012 (thesis)). Universitas Andalas, 2014.

13. Surianto, Sari NPP, Jurni. Hubungan kepemimpinan kepala ruangan dan lingkungan kerja dengan kepuasan kerja perawat di Pavilium Catelia RSUD Undata (The association between chief of ward's leadership and working environment with nurses' job satisfaction in Catelia Paviliun Undata Hospital). Jurnal Kesehatan Tadulako. 2016; 2(1): 13-22.

14. Nurhayani ST. Hubungan karakterisitik perawat pelaksana dengan kemampuan kepala ruangan melakukan bimbingan (coaching) menurut persepsi perawat pelaksana di ruang rawat inap Rumah Sakit Haji Jakarta (tesis) (The association of nurses' characteristics and the ability of chief of ward in coaching, perceived by nurses, in inpatient ward Haji Hospital Jakarta (thesis)). Universitas Indonesia, 2011.

15. Paramita GP, Rosa EM. Praktek kolaborasi dokter-perawat terhadap kepuasan kerja dokter umum di RSUD Nganjuk (The association of doctors-nurses collaboration and general practitioner's job satisfaction at Nganjuk Hospital). Jurnal Medicoeticolegal dan Manajemen Rumah Sakit. $2014 ; 3(1)$.

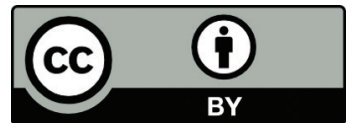

This work is licensed under a Creative Commons Attribution 